\title{
Imaging of Cystic Fibrosis Lung Disease and Clinical Interpretation
}

\section{Bildgebung der Lunge bei Mukoviszidose und klinische Interpretation}

Authors

Affiliations
M. O. Wielpütz ${ }^{1,2,3}$, M. Eichinger ${ }^{1,2,3}$, J. Biederer ${ }^{1,2,4}$, S. Wege ${ }^{5}$, M. Stahl' ${ }^{2,6}$, O. Sommerburg ${ }^{2,6}$, M. A. Mall ${ }^{2,6,7}$, H. U. Kauczor ${ }^{1,2,3}$, M. Puderbach ${ }^{1,2,3,8}$

Affiliation addresses are listed at the end of the article.

\section{Key words}

- thorax

- CT-quantitative

- tracheobronchial tree

- MR-functional imaging

- fibrosis, cystic received $\quad 8.12 .2015$

accepted $\quad 8.3 .2016$

Bibliography

DOI http://dx.doi.org/

10.1055/s-0042-104936

Published online: 13.4.2016

Fortschr Röntgenstr 2016; 188:

834-845 @ Georg Thieme

Verlag KG Stuttgart · New York .

ISSN 1438-9029

\section{Correspondence}

\section{Dr. Mark Oliver Wielpütz}

Diagnostic and Interventional

Radiology, University Hospital of Heidelberg

Im Neuenheimer Feld 110

69120 Heidelberg

Germany

Tel.: ++ 49/6221/566410

Fax: ++49/62 21/56 5730

mark.wielpuetz@med.uni-

heidelberg.de

\section{Zusammenfassung}

\section{$\nabla$}

Die progressive Lungenerkrankung bestimmt Morbidität und Mortalität der autosomal-rezessiv vererbten Mukoviszidose (Cystische Fibrose, $\mathrm{CF}$ ). Die Implementierung der $\mathrm{CF}$ in das Neugeborenen-Screening erlaubt eine Diagnosestellung häufig bereits in einem präsymptomatischen Stadium. Verbesserungen der Therapie haben zudem eine stetig zunehmende Lebenserwartung ermöglicht, sodass die Mehrzahl der Patienten heute erwachsen ist. Da bildgebende Verfahren detaillierte Informationen über den regionalen Krankheitsverlauf bieten, werden heute Kontrollen in regelmäßigen Abständen empfohlen. Röntgenaufnahmen des Thorax, die Computertomografie (CT) und die Magnetresonanztomografie (MRT) stehen zur Verfügung - jedes Verfahren mit spezifischen Stärken und Schwächen, sodass die Wahl des Verfahrens an die individuelle klinische Situation des Patienten angepasst werden kann. Die CT bietet die höchste Detailauflösung und kann mittels Software nachverarbeitet werden, welche Atemwegsveränderungen quantitativ erfassen kann und potenziell eine objektivere Schweregradeinteilung ermöglicht. Die CT hat daher die Röntgenaufnahme an spezialisierten Zentren weitgehend abgelöst. Entsprechend ist die Strahlenexposition der CF-Erkrankten angestiegen, die altersbedingt besonders sensibel für ionisierende Strahlen sind und während ihres Lebens eine relevante Dosis akkumulieren können. Die MRT als alternatives strahlungsfreies Schnittbildverfahren stellt die typischen morphologischen Veränderungen der $\mathrm{CF}$ mit vergleichbarer klinischer Information bei etwas geringerer Detailauflösung dar. Mehr als jedes andere Verfahren ermöglicht die MRT eine Beurteilung der regionalen Lungenfunktion, wobei sich die zeitlich hoch aufgelöste Perfusions-MRT als praktikabel erwiesen hat.

\section{Abstract \\ $\nabla$}

Progressive lung disease in cystic fibrosis (CF) is the life-limiting factor of this autosomal recessive genetic disorder. Increasing implementation of $\mathrm{CF}$ newborn screening allows for a diagnosis even in pre-symptomatic stages. Improvements in therapy have led to a significant improvement in survival, the majority now being of adult age. Imaging provides detailed information on the regional distribution of CF lung disease, hence longitudinal imaging is recommended for disease monitoring in the clinical routine. Chest X-ray (CXR), computed tomography $(\mathrm{CT})$ and magnetic resonance imaging (MRI) are now available as routine modalities, each with individual strengths and drawbacks, which need to be considered when choosing the optimal modality adapted to the clinical situation of the patient. CT stands out with the highest morphological detail and has often been a substitute for CXR for regular severity monitoring at specialized centers. Multidetector CT data can be post-processed with dedicated software for a detailed measurement of airway dimensions and bronchiectasis and potentially a more objective and precise grading of disease severity. However, changing to CT was inseparably accompanied by an increase in radiation exposure of CF patients, a young population with high sensitivity to ionizing radiation and lifetime accumulation of dose. MRI as a cross-sectional imaging modality free of ionizing radiation can depict morphological hallmarks of CF lung disease at lower spatial resolution but excels with comprehensive functional lung imaging, with time-resolved perfusion imaging currently being most valuable.

Key Points:

> Hallmarks are bronchiectasis, mucus plugging, air trapping, perfusion abnormalities, and emphysema.

Imaging is more sensitive to disease progression than lung function testing. 
Kernaussagen:

- Bildgebende Zeichen der Mukoviszidose sind Bronchiektasen, Mukoidimpaktionen, Air-Trapping, Perfusionsstörungen und Emphysem.

Die Bildgebung ist sensitiver als die Lungenfunktionsprüfung für die Beurteilung der Krankheitsprogression.

- Die CT hat die höchste morphologische Auflösung, jedoch begleitet von bedeutsamer Strahlenexposition.

- Die MRT zeigt vergleichbare morphologische Details, ihre Stärke sind zusätzliche funktionelle Informationen.

- Die MRT stellt reversible Veränderungen wie Mukoidimpaktionen und Perfusionsstörungen sensitiv dar. $\checkmark \mathrm{CT}$ provides the highest morphological detail but is associated with radiation exposure.

- MRI shows comparable sensitivity for morphology but excels with additional functional information.

- MRI sensitively depicts reversible abnormalities such as mucus plugging and perfusion abnormalities.

Citation Format:

- Wielpütz MO, Eichinger M, Biederer J etal. Imaging of Cystic Fibrosis Lung Disease and Clinical Interpretation. Fortschr Röntgenstr 2016; 188: 834-845

\section{Introduction \\ $\nabla$}

Cystic fibrosis $(\mathrm{CF})$ remains the most common lethal hereditary disease among white populations. Progressive lung disease determines more than $90 \%$ of morbidity and mortality, but improvements in diagnostics and therapy have given rise to prolonged survival of $\mathrm{CF}$ patients in the past, averaging around 40 years [1]. Implementation of screening programs in specialized centers in Germany and other Western countries has led to earlier diagnosis [2], thus enabling treatment in a pre-symptomatic stage. Pulmonary function testing underestimates the early stages of CF lung disease and has limited predictive value in pulmonary exacerbations $[3,4]$. Imaging provides regional information on the distribution and severity of the different components of CF lung disease. The hallmarks of the CF lung are bronchiectasis as one early sign of lung damage, airway wall thickening, consolidations and atelectasis, as well as emphysema in advanced stages of lung disease. Mucus plugging as well as air trapping and perfusion impairment are linked to basic pathophysiology and are potentially reversible under therapy. Bronchiectatic destruction of lung lobes, dilatation of bronchial arteries and pulmonary hemorrhage are sequelae, which may require invasive treatment and ultimately, lung transplantation. Originally, chest $\mathrm{X}$-ray was employed to depict morphological changes in the $\mathrm{CF}$ lung [5]. It has often been replaced by computed tomography (CT) at specialized centers, because of its higher sensitivity for early and subtle changes in the CF lung [6-8]. However, the use of CT for short-term follow-up in infants and preschool children as well as lifelong longitudinal monitoring are accompanied by an accumulation of radiation dose $[9,10]$. Most recently, magnetic resonance imaging (MRI) has emerged as a radiation-free technique for assessing the CF lung [11, 12]. Besides morphological information comparable to CT, MRI can depict several components of lung function, i.e. respiratory movements, ventilation and perfusion. CXR, CT and MRI each have intensively studied individual strengths and drawbacks. Based on the experience at our center, we intend to give an overview of the presentation of CF lung disease in the different imaging techniques, their current status regarding their application in the clinical routine, and to provide the reader with a rationale to decide on the appropriate modality tailored to the individual clinical question. Profound knowledge of the Fleischner Society's terminology for airway disease is pivotal $[13,14]$. A look at future MRI applications is given to conclude this review.

\section{Technical aspects and requirements \\ $\nabla$ \\ Chest X-Ray (CXR)}

A posterior-anterior as well as a lateral view is recommended in adolescents and adults. A study employing systematic scoring could show that the lateral view does not contain relevant additional information and may be omitted in young children [15].

\section{Computed Tomography (CT)}

German and international guidelines on CT protocols for CF are missing, and many different acquisition techniques for different age groups have been discussed in the past decade. Some authors have suggested using limited slice sampling to restrict radiation exposure $[8,16]$. Non-contrast-enhanced multidetector CT with full volume coverage and reconstructed overlapping slice thicknesses of preferably $1.5 \mathrm{~mm}$ or less has the highest sensitivity for morphological changes and should be given preference over incremental high-resolution CT $[17,18]$. These datasets not only allow for exact comparison of follow-up exams, multiplanar reformats and maximum intensity projections (MIP) for better identification of airway changes, but also enable dedicated postprocessing with advanced software tools [17, 19]. Age-adapted low-dose acquisitions with an effective radiation dose of less than $2 \mathrm{mSv}$ even in adults are sufficient for the evaluation of morphological changes including ground glass opacities and mosaic perfusion [20]. A combined protocol of end-inspiratory with end-expiratory scans is generally recommended to enhance the sensitivity for small airway obstruction [21, 22], and both acquisitions may be performed with similar exposure settings, but added radiation dose ( $\bullet$ Table 1 ). At the same time, all technical potential available for dose reduction must be exploited, such as reduction of overbeaming, automatic tube current modulation, iterative reconstruction, etc. $[23,24]$. 0 Table 1 seeks to summarize the most important protocol components for CT.

In young children unable to cooperate, CT scanning may require sedation. High-end CT scanners provide a high-pitch mode that delivers nearly artifact-free images even in free-breathing children without the need for sedation ( $\bullet$ Table 1 ). To acquire paired inspiratory and expiratory scans in uncooperative children, usually anesthesia, intubation and controlled ventilation are necessary [25]. However, this would rather be applied for research than for clinical imaging.

The i. v. application of iodinated contrast agents in CF is restricted to specific situations, such as pulmonary emergencies including pulmonary arterial embolism and hemorrhage. In advanced CF lung disease, hypertrophy of bronchial arteries frequently occurs and can be identified by CT and MR angiography alike. Currently, CT angiography is recommended to identify and delineate the 
course of dilated bronchial arteries when embolization procedures are planned [26] ( $\bullet$ Table 1 ).

\section{Magnetic Resonance Imaging (MRI)}

Lung proton MRI sequences with dedicated protocols are now readily provided by all large vendors [27]. Depending on patient size and ability to breath-hold, it is useful to prepare three separate protocols ( $\bullet$ Fig. 1, $\odot$ Table 2 ) $[11,28,29]$. Each should start with balanced steady-state free precession (bSSFP) sequences. Acquired in free-breathing, a negative distance factor $(-50 \%$ slice thickness) provides an overview of respiratory movements. Airway changes are assessed using spoiled gradient echo sequences (GRE). In children unable to breath-hold, a T1-weighted fast spin echo (FSE) sequence and averaging may be used. Mucus plugging within the large airways is sensitively depicted by T2-weighted sequences, for example a half-Fourier single shot fast spin echo acquisition. A four-dimensional dynamic contrast-enhanced perfusion study (spoiled GRE) at high temporal resolution ( $1.5 \mathrm{~s}$ per lung volume with 20 - 30 consecutive acquisitions) with intravenous application of gadolinium-based contrast by a power injector is recommended [27]. The common side effects of i. v. contrast injection, dose as well as national prescription regulations need to be considered with respect to patient age. For a quick review of these large datasets, perfusion maps with subtraction of the pre-contrast series from the series with the highest parenchymal enhancement are very helpful. Multi-phasic MR angiography at high spatial resolution can be added for the confident identification of dilated bronchial arteries, for which the perfusion study may serve to determine circulatory time (contrast volume may be split into doses of $20-50 \%$ for perfusion imaging and $50-$ $80 \%$ for angiography). In case of incorrect timing of contrast bolus or image deterioration due to coughing or patient movement,

\begin{tabular}{|c|c|c|c|}
\hline & $0-5$ years & $6-18$ years & $\geq 18$ years \\
\hline detector lines & $\geq 16$ & $\geq 16$ & $\geq 16$ \\
\hline acquisition & volumetric & volumetric & volumetric \\
\hline tube potential (kV) & $80-100$ & $80-100$ & 120 \\
\hline $\begin{array}{l}\text { effective tube } \\
\text { current (mAs) }\end{array}$ & $\leq$ bodyweight $(\mathrm{kg})+5$ [69] & $\leq$ bodyweight $(\mathrm{kg})+5[69]$ & "low-dose"1 \\
\hline $\begin{array}{l}\text { automatic current } \\
\text { modulation }\end{array}$ & yes & yes & yes \\
\hline reconstruction kernel & sharp, medium soft & sharp, medium soft & sharp, medium soft \\
\hline iterative reconstruction & yes & yes & yes \\
\hline $\begin{array}{l}\text { reconstructed slice } \\
\text { thickness }\end{array}$ & $\leq 1.5 \mathrm{~mm}$ & $\leq 1.5 \mathrm{~mm}$ & $\leq 1.5 \mathrm{~mm}$ \\
\hline $\begin{array}{l}\text { reconstruction } \\
\text { increment }\end{array}$ & $\geq 25 \%$ overlap & $\geq 25 \%$ overlap & $\geq 25 \%$ overlap \\
\hline high-pitch mode & fixation, no sedation & yes & if dyspnoeic \\
\hline sedation & if no high-pitch mode & no & no \\
\hline expiratory scan & $\begin{array}{l}\text { study conditions, intubation } \\
\text { required [25] }\end{array}$ & yes & yes \\
\hline
\end{tabular}

Table 1 Overview of CT acquisition parameters.

Tab. 1 Überblick über die CT-Akquisitionsparameter.

${ }^{1}$ An exact definition of low-dose is currently missing. Typical effective mAs is $20-70 \mathrm{mAs}$, adapted to bodyweight.

Niedrigdosis („low-dose“) ist bislang nicht exakt definiert. Typische effektive mAs zwischen 20 - 70 mAs nach Körpergewicht.

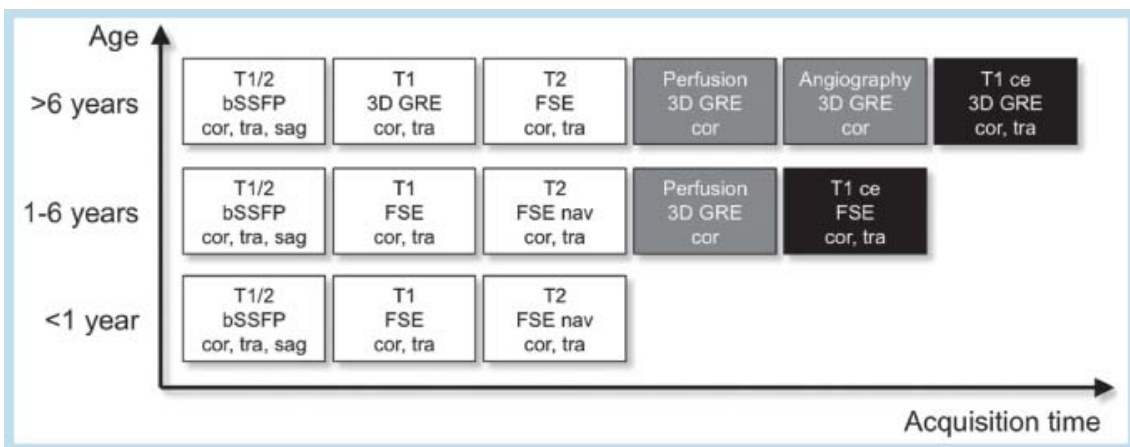

Fig. 1 MRI protocol options. Three separate basic MRI protocols should be kept ready to use, optimized to the patient's ability to breath-hold and comply with the procedure. cor = coronary plane, tra = transverse plane, sag = sagittal plane, bSFFP = balanced steady-state free-precession sequence; $50 \%$ slice overlap should be used. FSE = fast spin echo sequence; for T1-weighted acquisitions averaging 3-4x should be used to compensate for breathing artifacts; for T2-weighted acquisitions a half-fourier single shot technique or rotating phase encoding should be used. nav = navigator techniques. 3D GRE = three-dimensional gradient echo sequence; echo-sharing should be used for perfusion imaging. ce = contrast-enhanced.
Abb.1 Optionen für MRT-Protokolle. Es ist empfehlenswert drei separate MRT-Protokolle bereitzuhalten, die an die individuelle Fähigkeit des Patienten zur Kooperation und zum Atemanhalt angepasst sind. cor $=$ koronare Schicht, tra = transversale Schicht, sag = sagittale Schicht, bSFFP = Balanced Steady-State Free-Precession-Sequenz; 50 \% Schichtüberlappung sollte gewählt werden. FSE = Fast-Spin-Echo-Sequenz; für T1-gewichtete Akquisitionen sollten 3-4 Mittelungen als Kompensation für Atembewegungen gewählt werden; für T2-gewichtete Akquisitionen sollte eine Half-Fourier Single-Shot-Technik oder rotierende Phasenkodierung gewählt werden. nav = Navigatortechnik. 3D-GRE = dreidimensionale Gradientenechosequenz; Echo-Sharing sollte für die Perfusionsmessung verwendet werden. $\mathrm{ce}=$ kontrastmittelverstärkt. 
recirculating vessel contrast is still sufficient to acquire additional T1-weighted images with reasonable angiographic quality. The overall room time for this imaging protocol approximates $30 \mathrm{~min}$. The standard protocol ( $\bullet$ Fig. 1) may be further extended to the specific needs, e.g. by adding further functional studies and cardiac sequences [30]. Moreover, ultra-short echo time (UTE) sequences as introduced recently offer a potentially high parenchymal signal and may produce CT-like images of the CF lung, but their added value compared to the established CF MRI protocols has not yet been assessed [31].

Routine sedation is usually necessary in preschool children $(<6$ years). For propofol an incidence of up to $42 \%$ for atelectasis may mask or even simulate relevant pathology [11, 32]. Chloral hydrate or phenobarbital have been reported to produce less atelectasis [33], and chloral hydrate, administered rectally or orally under monitoring by a pediatrician, has been used at our institution as the preferred medication with satisfactory results for the past 10 years [11].

\section{Morphological changes of the CF lung}

$\nabla$

\section{Airways}

Characteristic airway abnormalities in CF are mucus plugging together with inflammatory airway wall thickening and progressive bronchiectasis ( $\bullet$ Fig. $2-4$ ) that usually appear in heterogeneous combinations of different severity $[25,34]$. Recent CT and MRI studies in infants and young children with CF also demonstrated high variability and regional heterogeneity of early lesions throughout the lung without predilection for a specific region that, especially in early disease, cannot be captured by global measures, such as spirometry, due to functional compensation by structurally normal areas $[8,11,18]$. Bronchiectasis is considered one of the earliest irreversible structural abnormalities detected by morphologic imaging even in asymptomatic infants identified by newborn screening, and also correlates with disease severity and exacerbation rate $[6,25]$. Bronchiectasis may appear as superimposed line shadows and ring shadows on CXR, depending on the course of the airway in relation to the image plane $(\bullet$ Fig. 3, 4) $[13,35]$. Affection of the small airways, which are usually not visualized by CXR, may lead to visibility of grouped mottled shadows. CXR has the lowest sensitivity for early changes in the CF lung, whereas CT is considered the reference standard because of its high isotropic resolution. Multiplanar reformats help to identify central to peripheral bronchiectasis. However, even in MDCT, the visualization of small airways is precluded by the system-inherent resolution of $200-300 \mu \mathrm{m}$ [17]. If small airways (by convention smaller than $1 \mathrm{~mm}$ in diameter) are affected by wall thickening, mucus plugging or bronchiectasis (usually a combination of all three), they may increase in size over the resolution threshold and become visible as centrilobular nodules, often grouped with a tree-in-bud appearance. In more advanced disease, sacculations, or cystic bronchiectasis, may be observed, which ultimately may lead to the destruction of a whole lung lobe.

As expected from the higher spatial resolution, MDCT is superior to MRI in the depiction of small peripheral airways. However, the aforementioned pathological changes of the CF lung represent high signal components against the black background of healthy lung tissue ("plus pathologies"). This facilitates detection and results in a comparably high sensitivity of MRI for most pathologies as with CT. Recent CT studies reported bronchiectasis in approx. $30 \%$ at the age of 3 months, and progression to approx. $60 \%$ at the age of 3 years $[8,25]$. The aforementioned pathological changes of the CF lung represent high signal components against the black background of healthy lung tissue ("plus pathologies"). This facilitates detection and results in a comparably high sensitivity for MRI as with CT for most pathologies [29]. MRI detected a similar

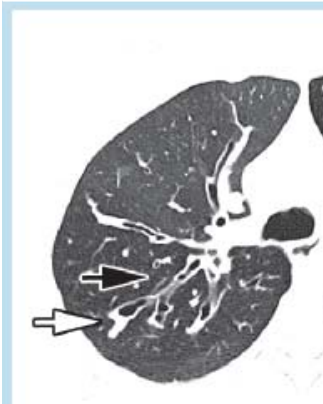

a
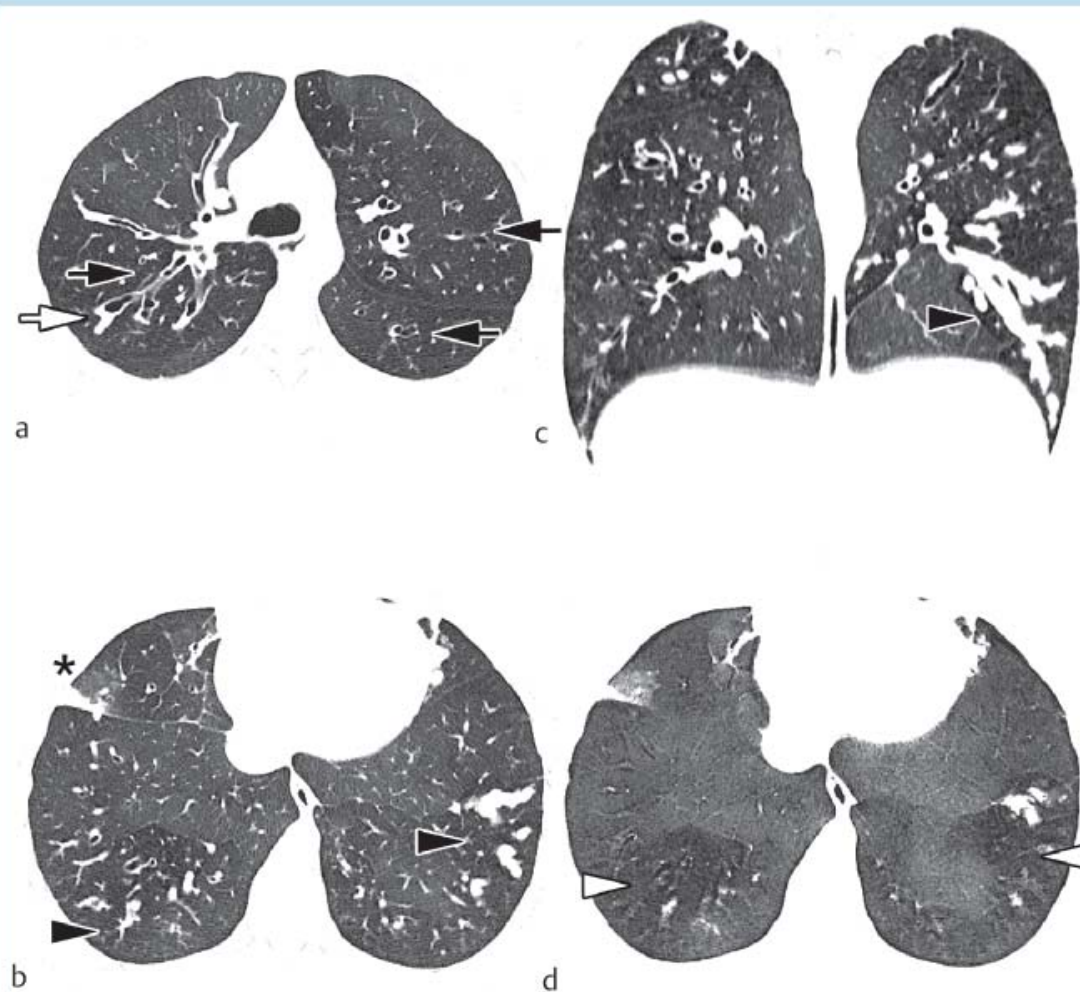

Fig. 2 Typical CT appearance of CF lung disease. a, b This adolescent male CF patient shows typical bronchiectasis (black arrow) together with wall thickening and mucus plugging (white arrow). A consolidation and pleural thickening (asterisk) is present in the middle lobe. $\mathbf{c}$ In the left lower lobe, bronchoceles are present (black arrowhead), embedded in an area of reduced lung density (mosaic perfusion). $\mathbf{d}$ Minimum intensity projections (MinIP) enhance the detection of such low-density areas, (white arrowhead) which are due to hyperinflation and reduced perfusion.

Abb.2 Typische Merkmale der CF-Lungenerkrankung im CT. a, b Typische Bronchiektasen (schwarzer Pfeil) bei einem männlichen Jugendlichen mit CF begleitet von Bronchialwandverdickungen sowie Mukoidimpaktion (weißer Pfeil). Eine Konsolidierung sowie angrenzende pleurale Verdickung (Sternchen) ist im Mittellappen erkennbar. c Der linke Unterlappen weist Bronchozelen auf (schwarzer Pfeilkopf), welche in ein Lungenareal reduzierter Dichte eingelagert sind (Mosaikperfusion). $\mathbf{d}$ Minimum-Intensitäts-Projektionen (MinIP) können die Sichtbarkeit solcher Areale mit reduzierter Dichte (weißer Pfeilkopf) verbessern, welche die Folge einer lokalen Überblähung und reduzierter Perfusion sind. 


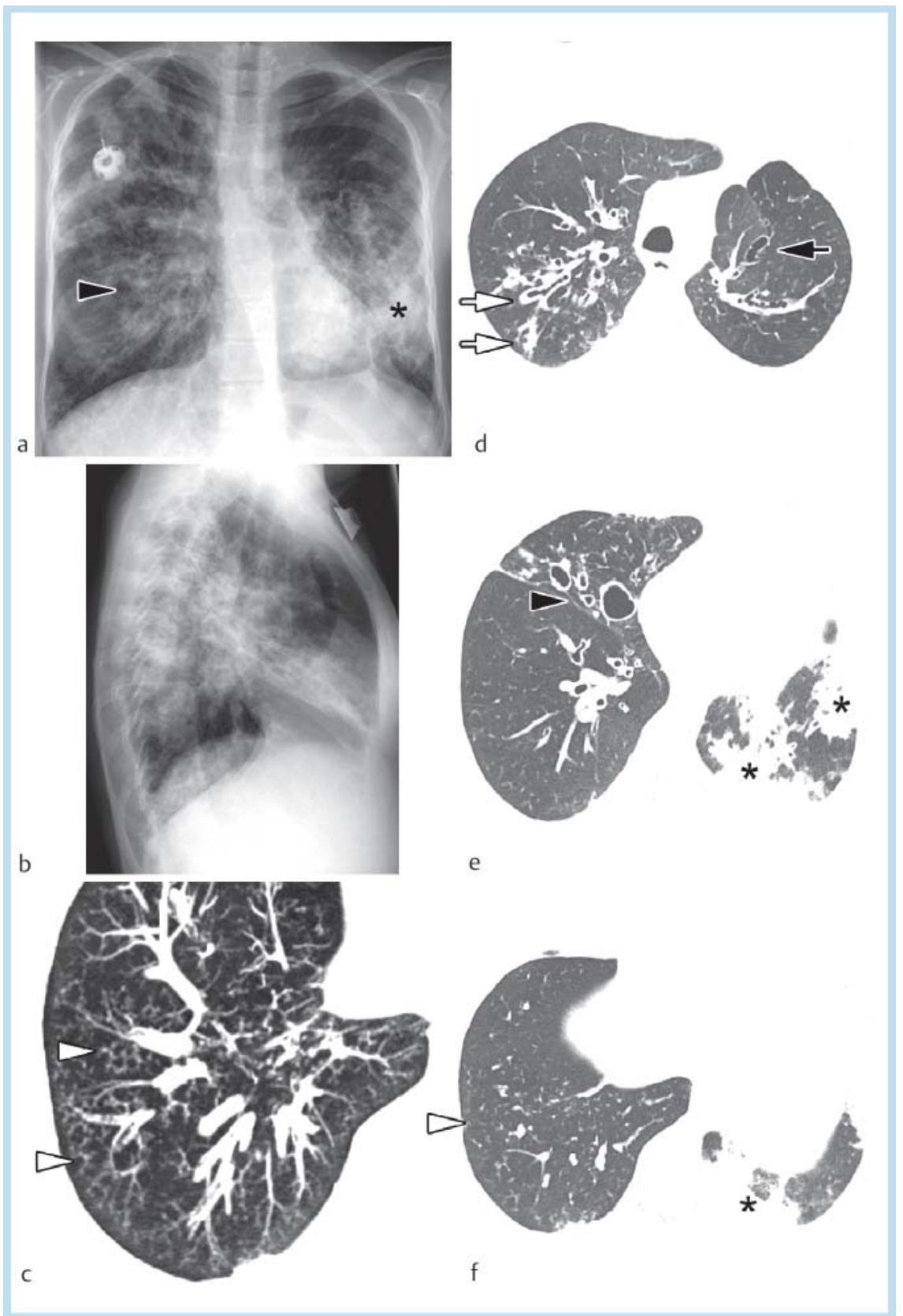

Fig. 3 Severe exacerbation of CF lung disease on CXR and CT. This 18year-old female was hospitalized for intravenous antibiotic therapy for severe pulmonary exacerbation. a, b, d, e She presented with more extensive bronchiectasis than the patient in $\bullet$ Fig. 2, with partly thin-walled bronchiectasis (black arrow), but also in combination with wall thickening and mucus plugging (white arrow). It is clear that a layer of mucus on the airway surface cannot be distinguished from inflammatory wall-thickening by CT. Especially the middle lobe shows destructive cystic bronchiectasis (black arrowhead), which is typical for CF (sometimes also called sacculations). The right superior lobe as well as the left lung were affected by patchy consolidations (asterisk), the latter accompanied by a volume loss of the left hemithorax. Here, remaining aerated lung areas showed little structure such as airways or vasculature. c, $\mathbf{f}$ Small nodules (white arrowhead) of the right inferior lobe were found to have a centrilobular distribution (tree-inbud pattern) as evidenced by a maximum intensity projection (MIP 10/ $2 \mathrm{~mm}, \mathbf{c}$, and are thus related to small airways disease. Note the sparing of the subpleural space.
Abb. 3 Schwere Exazerbation der CF-Lungenerkrankung in der CXR und der CT. Die 18-jährige Patientin wurde zur intravenösen antibiotischen Therapie bei schwerer pulmonaler Exazerbation stationär aufgenommen. a, b, d, e Im Vergleich zum Patienten aus $\bigcirc$ Abb. 2 wies sie stärker ausgeprägte Bronchiektasen auf, welche teilweise dünnwandig (schwarzer Pfeil) und teilweise in Kombination mit Wandverdickung und Mukoidimpaktionen (weißer Pfeil) imponierten. Dieses Beispiel verdeutlicht nochmals, das mittels CT ein oberflächlicher Mukusbelag nicht von einer entzündlichen Wandverdickung unterschieden werden kann. Insbesondere der Mittellappen zeigte destruktive zystische Bronchiektasen (schwarzer Pfeilkopf), welche typisch für die CF sind (auch Sakkulationen genannt). Der rechte Oberlappen sowie die gesamte linke Lunge waren von fleckigen Konsolidierungen betroffen (Sternchen), letztere begleitet von einer Volumenminderung des linken Hemithorax. Verbliebene belüftete Lungenanteile zeigten wenig strukturelle Merkmale wie Atemwege oder Gefäße. c, f Die Mikronoduli (weißer Pfeilkopf) im rechten Unterlappen wiesen ein zentrilobuläres Muster auf (sog. Tree in bud-Muster), wie die Maximum-IntensitätsProjektion (MIP 10/2 mm, c belegt, und sind daher durch eine Erkrankung der kleinen Atemwege verursacht. Beachte die Aussparung des unmittelbaren Subpleuralraumes. 


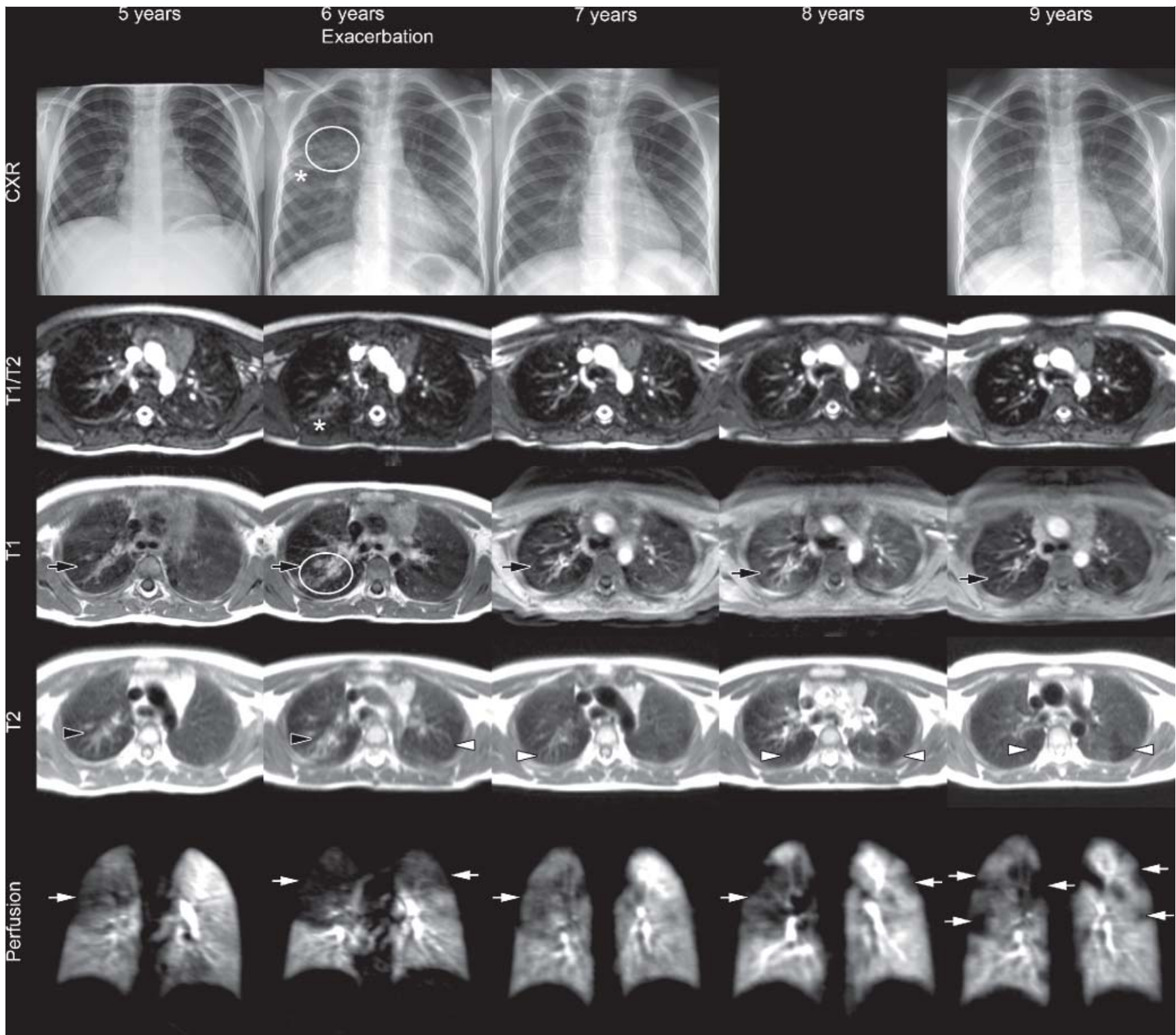

Fig. 4 Longitudinal surveillance with CXR and MRI. This female patient with CF participates in our surveillance imaging program with annual routine follow-up. Irreversible bronchiectasis (black arrow) could be identified in the right superior lobe from age 5 . These airways showed mucus plugging (black arrowhead) at age 5 and 6, which was reversible thereafter. Around this area as well as in the left superior lobe reduced parenchymal signal on T2 (white arrowhead) similar to mosaic perfusion on CT was present, with different severity over time. Perfusion abnormalities (white arrow) were detected at all ages, but with significantly different severity. Note that perfusion abnormalities also correlate with the areas of reduced signal on T2. At age 6, the subject had a pulmonary exacerbation, which was evidenced on imaging by the presence of a right superior lobe consolidation (circle) with adjacent pleural reaction (asterisk) and more severe perfusion abnormalities. One year later (therapy was enacted immediately), mucus plugging, consolidation and perfusion abnormalities were alleviated.
Abb.4 Longitudinale CXR und MRT zum Krankheitsmonitoring. Diese weibliche CF-Patientin nimmt an dem lokalen Programm mit jährlicher CXR und MRT zum Monitoring der Krankheitsaktivität teil. Irreversible Bronchiektasen (schwarzer Pfeil) sind bereits ab dem 5. Lebensjahr sichtbar. Diese Atemwege zeigten im Alter von 5 und 6 Jahren Mukoidimpaktionen (schwarzer Pfeilkopf), welches hiernach reversibel war. Um dieses Areal ebenso wie im linken Oberlappen fand sich ein reduziertes Parenchymsignal in der T2-Wichtung (weißer Pfeilkopf), vergleichbar der Mosaikperfusion in der $C T$, mit unterschiedlicher Ausprägung zu den unterschiedlichen Zeitpunkten. Perfusionsstörungen (weißer Pfeil) zeigten sich zu allen Zeitpunkten, jedoch mit deutlich variabler Ausprägung. Beachte, dass das reduzierte Parenchymsignal in T2-gewichteten Aufnahmen mit den Perfusionsstörungen korreliert. Im Alter von 6 erlebte die Patientin eine pulmonale Exazerbation, welche in der Bildgebung durch eine Konsolidierung im rechten Oberlappen (Kreis) mit angrenzender Pleuraverdickung (Sternchen), und stark ausgeprägten Perfusionsstörungen auffiel. Im folgenden Jahr (eine Therapie wurde umgehend eingeleitet) waren Mukoidimpaktionen, Konsolidierung und Perfusionsstörungen wieder deutlich gebessert.

Mucus plugging is linked to the basic ion-transport defect and constitutes the second most frequent morphological abnormality ( Fig. 2 -4) [11, 36]. Whereas mucus plugging received little attention in recent $\mathrm{CT}$ studies, MRI detected a high overall prevalence of mucus plugging of approx. $63 \%$ of cases, making (mean age: 3.1 years) [11]. In a direct comparison, MRI showed a high correlation with CT-diagnosed structural abnormalities in a CF population aged 7 - 42 years (mean age: 16.7 years) [29]. Even key features such as the tree-in-bud pattern could be observed. 
it the second most frequent morphological abnormality in clinically stable infants and preschool children with CF (mean age: 3.1 years) [11]. Neither CT nor CXR can distinguish mucus on the airway surface from inflammatory wall thickening of larger airways ( $\bullet$ Fig. 2,3 ). The possibility for different tissue contrasts in combination with contrast enhancement is a clear advantage of MRI. Wall thickening due to edema will lead to high signal intensity on T2-weighted images, reflecting active inflammation ( Fig. 4). Contrast enhancement of the airway wall on T1weighted sequences is also a marker of inflammation, whereas intraluminal fluid will show a low signal. Importantly, mucus plugging may become a useful outcome measure in early $\mathrm{CF}$ lung disease as a potentially reversible abnormality [11, 12, 36].

\section{Parenchyma}

Consolidations are typical signs of infection and are found in pulmonary exacerbations in CF. In many cases, an atelectasis with reduced volume and displacement of the pulmonary fissures occurs in exacerbation, unlike typical lobar pneumonia in otherwise healthy patients [37]. CXR usually has the lowest sensitivity, while CT and MRI perform equally well ( $\bullet$ Fig. 2 - 5) [38]. On MRI, consolidations stand out brightly on T2-weighted sequences ( $\bullet$ Fig. 4). In case of a destroyed segment or lobe, bronchiectasis embedded in persistent consolidation and volume loss are evident. In a group of 10 patients with pulmonary exacerbations (age range: 0 - 6 years, mean age: 3.7 years), consolidations on MRI were more frequent than in a comparable group in a clinically stable situation [11]. Moreover, they were alleviated under an-

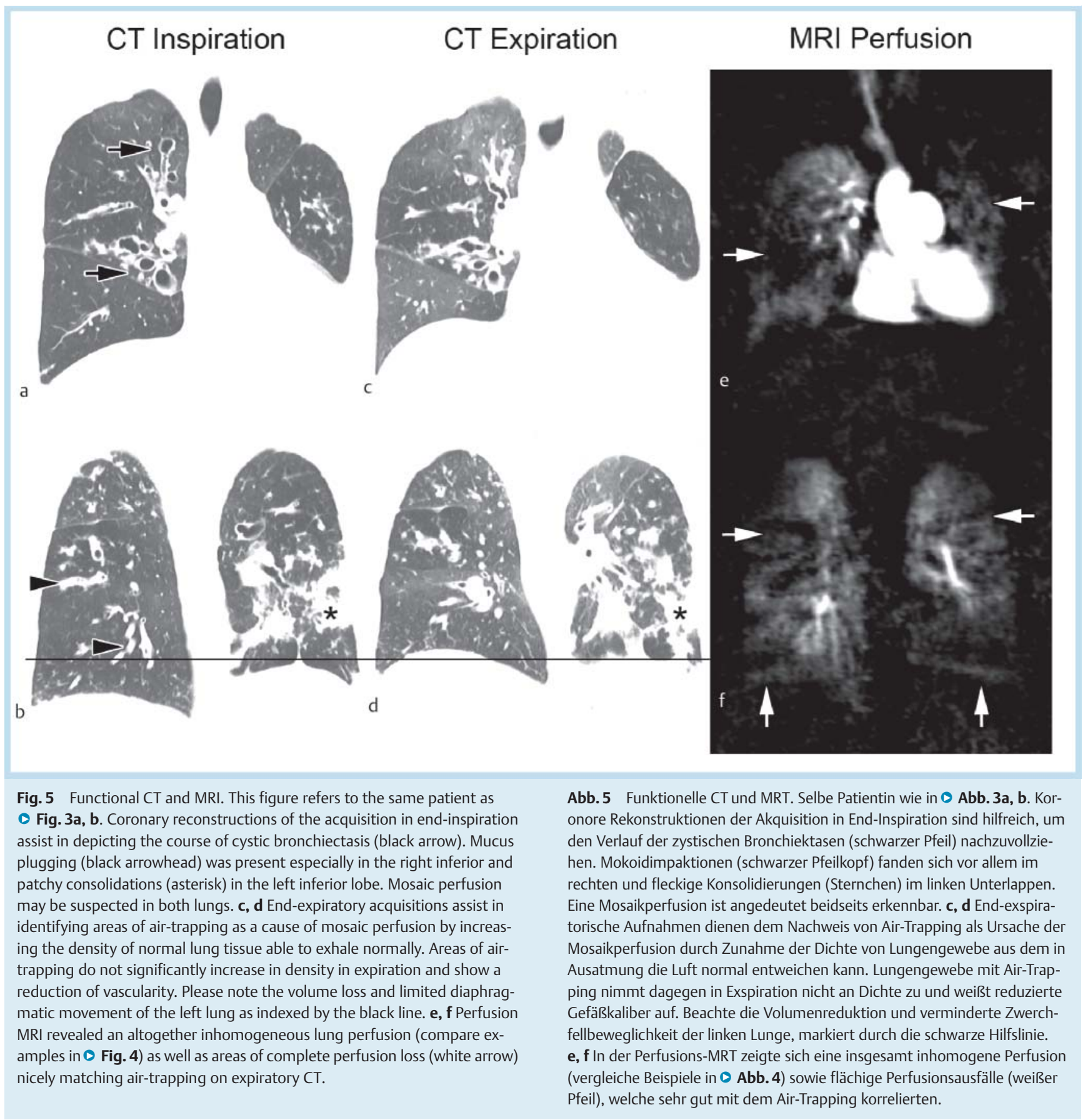


tibiotic therapy, making it a potentially reversible abnormality. However, mucus plugging and perfusion abnormalities seemed to play a greater role in exacerbation and were more responsive to treatment than consolidations [11]. Peripheral consolidations may lead to pleural thickening and enhancement of the adjacent pleura ( $\odot$ Fig. 2, 4) $[11,39]$. Recent work using quantitative CT has confirmed earlier histopathological descriptions that adolescent and adult CF patients develop emphysema (age range: 7 - 66 years, median age: 20.1 years) [ 40,41$]$. This is also supported by a mouse model showing that emphysema formation in advanced CF is pathophysiologically linked to emphysema in COPD [4244].

\section{Functional imaging - air trapping and lung perfusion \\ $\nabla$}

Small airway obstruction prevents air from being exhaled from lung volumes the size of a lobule to whole lobes. These have a reduced alveolar oxygen level and may be hyperinflated. The physiological effect called hypoxic pulmonary vasoconstriction (HPV, formerly "Euler-Lilljestrand-Reflex") leads to reduced perfusion to such lung areas in order to prevent intrapulmonary shunting. In airway diseases such as $\mathrm{CF}$, airway obstruction frequently occurs and thus leads to a redistribution of the pulmonary blood volume. On inspiratory CT scans, the reduced capillary blood content may be detected by a reduced parenchymal density in Hounsfield Units (HU). It is often surrounded by and sharply delineated against normal lung and shows reduced vessel numbers and calibers also. Such an appearance was termed mosaic perfusion $[13,14,45]$. Its visual perception may be enhanced by endexpiratory CT acquisitions: During normal expiration, lung volume as well as the amount of air per voxel decreases, thus leading to an increase of its density value on CT. As compared to normal, lung areas with small-airway obstruction do not significantly change volume or increase in density on expiratory acquisitions. Thus, the density difference between areas of airway obstruction and normal lung is expanded, increasing the sensitivity of CT for detection. If a mosaic of different densities is seen on expiratory $C T$, it is generally termed "air trapping" $[13,14]$. Using expiratory $\mathrm{CT}$, air trapping has been described in approx. $70 \%$ of newborns, infants and preschool children with CF (age range: $0-5$ years) (० Fig. 2, 5) [8, 18, 25].

Similar to mosaic perfusion, areas of lower signal intensity may also be visible on T2-weighted as well as post-contrast T1weighted sequences with MRI due to the higher parenchymal signal of normal lung, but the sensitivity may be lower than with CT (๑ Fig.4). The effect of HPV implies that imaging of lung perfusion approximates lung ventilation [46]. Thus, perfusion MRI should - in theory - identify identical areas of pathology as air trapping on expiratory CT. However, data on direct comparison is missing. Typical patchy or wedge-shaped perfusion defects occur on MRI and it was shown that these areas of hypoperfusion correlate with the degree of parenchymal changes in pediatric (age range: $0-6$ years, mean age: 3.1 years) and adolescent (age range: $11-19$ years, median age: 16 years) CF patients ( 0 Fig. $\mathbf{4}$, 5) $[11,47]$. Abnormal perfusion on MRI was already detected in the first year of life, with an overall prevalence of $85 \%$ in preschool children, comparable to the aforementioned prevalence of air trapping [11]. Maybe more importantly, perfusion alterations occurred even without detectable parenchymal changes [11]. This suggests that air trapping and perfusion abnormalities may be the earliest signs of disease detectable in the CF lung, even before morphological changes become visible. Air trapping/perfusion abnormalities may reflect reversible disease and hold the possibility for therapy monitoring [11], but may become fixed in advanced CF with extensive parenchymal damage.

\section{Scoring and quantitative imaging}

\section{$\nabla$}

To quantify disease severity and facilitate patient follow-up and monitoring of therapeutic effects in $\mathrm{CF}$, visual scoring systems have been developed for CXR (e. g. Chrispin-Norman Score, Brasfield Score, Wisconsin Score) [15, 35, 48, 49], CT (e.g. Bhalla Score, Helbich Score, Brody Score) [4, 50, 51], and more recently, MRI (Eichinger Score) [39]. These scoring systems are necessary because the described changes in the CF lung show a heterogeneous distribution within one patient and between different patients, and may intra-individually show a different course over time. Thus, the scores encompass structural changes (CXR, CT, MRI) as well as functional changes (air trapping on CT, perfusion abnormalities on MRI), and assign a numeric score to lung regions or lobes depending on the severity of the individual pathology. A previous study reported that the correlation of lung function parameters with CT was higher than with CXR, indicating that CT provides a more precise grading than CXR [52]. Most importantly, CT scoring proved to be superior over pulmonary function testing in detecting subtle disease progression [6], and has already been used to detect therapy response [7]. A more advanced approach uses a grid overlay on selected CT slices and allows a reader to assign a pathology to each lung-containing square, leading to semi-automatic scoring [53]. Still, automatic objective quantification of image information remains desirable. There is high potential in the direct quantification of airway changes by generation- and lobe-based quantitative post-processing of non-enhanced thin-slice CT datasets ( $\boldsymbol{0}$ Fig. 6). Putative imaging biomarkers such as wall thickness or airway diameter, air trapping, and emphysema may be derived [19, 40], but a high amount of automation is necessary to avoid any user interaction and bias [19].

Dedicated software tools for the quantification of MRI perfusion based on the indicator dilution theory are already available, which can at least perform the initial step of segmenting the lung from the $4 \mathrm{D}$ perfusion dataset $[54,55]$. Four parameters have been developed to reflect the characteristics of pulmonary hemodynamics: pulmonary blood flow (PBF), blood volume (PBV), mean transit time (MTT), and time-to-peak (TTP) [56]. Using a modification of these parameters it could be shown that perfusion in the CF lung may not only be reduced by peak quantity but also delayed [57]. It has been speculated that delayed perfusion may reflect increased bronchial arterial supply in advanced lung disease. Because these receive blood from the systemic circulation, increased flow will result in a left-to-left shunt, which is still of uncertain clinical significance.

\section{Advanced ventilation and perfusion imaging with MRI $\nabla$}

An option for direct visualization of lung ventilation is the imaging of nuclei other than ${ }^{1} \mathrm{H}$, namely ${ }^{3} \mathrm{He}$ and ${ }^{129} \mathrm{Xe}$ [58]. By this approach, MRI after inhalation of the noble gas will display ventilated airspace only. Hyperpolarized ${ }^{3} \mathrm{He}-\mathrm{MRI}$ depicted a high number of ventilation defects in $\mathrm{CF}$ patients compared to healthy volunteers, which correlated with a decrease in lung function [59,60], but 
a
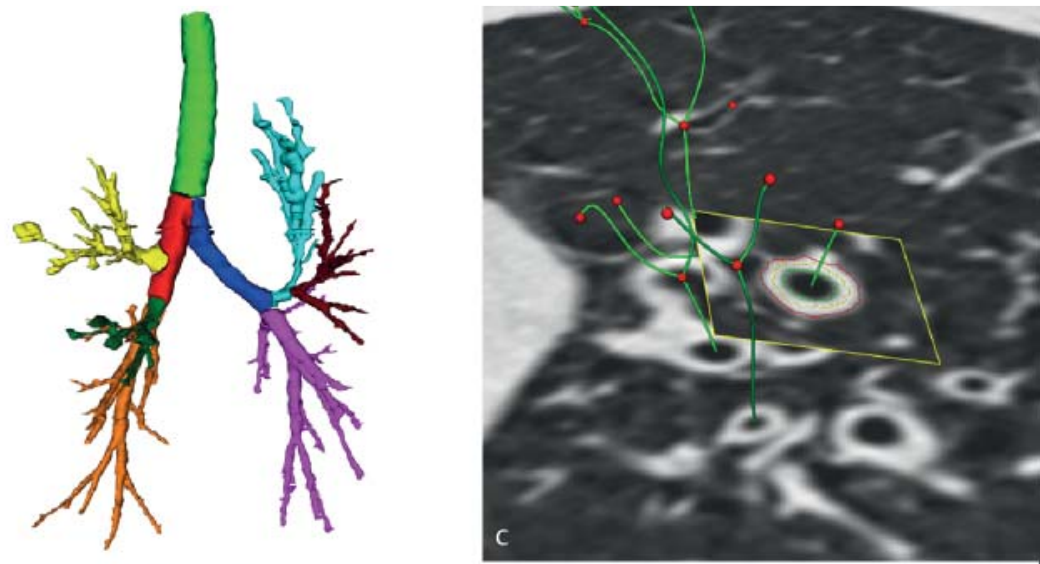

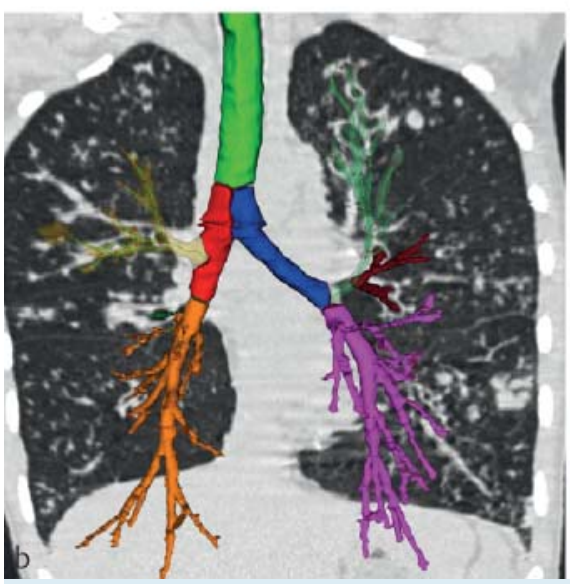

Fig.6 Quantitative $\mathrm{CT}$ post-processing. a The initial step of automatic airway analysis is the segmentation of the whole airway tree from the CT dataset. Bronchiectasis can nicely be seen as buddings at the end of an airway branch on the $3 \mathrm{D}$ volume rendering. $\mathbf{b} \mathrm{A}$ centerline is then calculated for each airway segment, which represents the long axis of each airway. c Subsequently, secondary reconstructions running perpendicular to the airway axis (centerline) are produced, which show an axial view for each airway segment. $\mathbf{d}$ On these, the inner (green line) and outer (red line) airway wall may be detected and measured by sophisticated algorithms. The yellow line marks the points of maximum wall attenuation. Images by YACTA, programming by Oliver Weinheimer, Heidelberg.

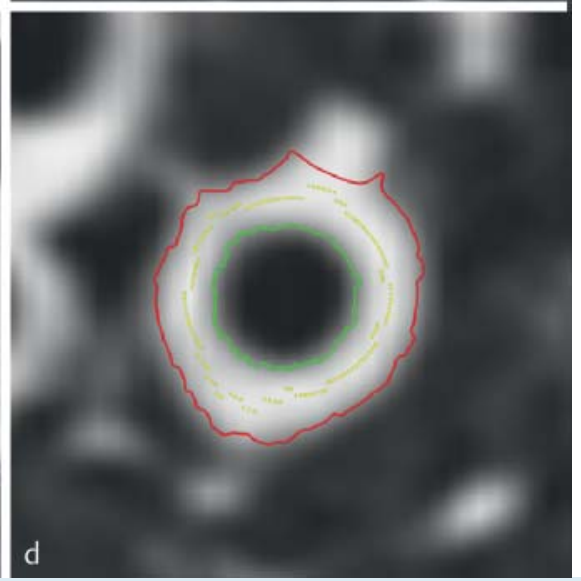

Abb.6 Quantitative CT-Nachverarbeitung. a Als erster Schritt einer automatischen Atemwegsanalyse erfolgt die Segmentierung des gesamten Atemwegsbaums aus einem CT-Datensatz. Bronchiektasen lassen sich leicht als Knospungen an den Enden der Atemwege in der $3 \mathrm{D}$ gerenderten Rekonstruktion erkennen. b Hiernach wird eine Mittellinie (Centerline) berechnet, die der Längsachse eines jeden Atemwegs folgt. c Sekundäre Rekonstruktionen senkrecht zur Atemwegsachse (Centerline) werden erstellt, die nun eine axiale Sicht des jeweiligen Atemwegssegments erlauben. d Auf diesen kann nun die innere (grüne Linie) und äußere (rote Linie) Begrenzung der Atemwegswand mittels spezieller Rechenalgorithmen detektiert werden. Die gelbe Linie zeigt die Punkte der höchsten Dichte der Atemwegswand. Bilder erstellt mit YACTA, programmiert von Oliver Weinheimer, Heidelberg. showed poor correlation with chest X-ray scoring [61]. Ventilation defects are present even in CF patients with normal lung function testing and may change after airway clearance treatment [62]. Sophisticated technical prerequisites and the price for noble gas isotopes make this promising research tool expensive and rather unlikely to be introduced into routine patient care.

A promising technique is the direct regional quantification of $\mathrm{T} 1$ relaxation times. As a physical parameter, it is thought to provide an objective parameter for the characterization of pulmonary tissue independent of scanner type or observer [63]. Preliminary results obtained in patients indicate that $\mathrm{T} 1$ relaxation time is significantly shorter in lungs affected by emphysema or cystic fibrosis [64]. Furthermore, T1 mapping can be combined with oxygen-enhanced MRI, which exploits the paramagnetic effect of molecular oxygen $\left(\mathrm{O}_{2}\right)$ for the indirect assessment of lung ventilation. The slope of $\mathrm{T} 1$ decrease at different oxygen levels correlated with perfusion abnormalities [65].

Another newly developed technique relies on the periodical signal changes of free-breathing bSSFP sequences at high temporal resolution induced by respiration and pulsatory blood inflow [66]. A mathematical Fourier decomposition separates these different frequency peaks and allows for the calculation of ventilation and perfusion maps. Preliminary results from patients with CF (age range: 0 - 30 years, median age: 4.1 years) show a good agreement with contrast-enhanced perfusion imaging [54] (๑ Fig. 7).

\section{Summary and outlook \\ $\nabla$}

Although many authors advocate regular imaging studies at specialized CF centers, data on the actual impact of imaging findings on treatment decisions and patient survival is lacking. Therefore, German and international guidelines usually do not specify at what age surveillance imaging of the CF lung should be started, or even which modality should be employed [67]. Chest CT is superior to CXR due to higher sensitivity for morphological changes in the CF lung, but routine surveillance CT acquisitions have sub- 
MRI
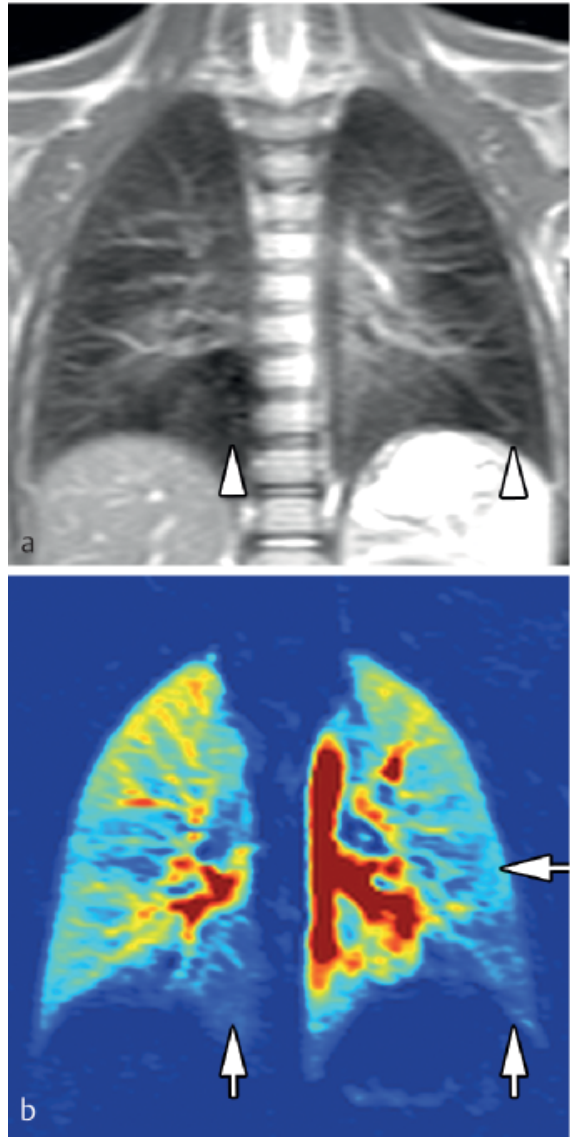

FD-MRI
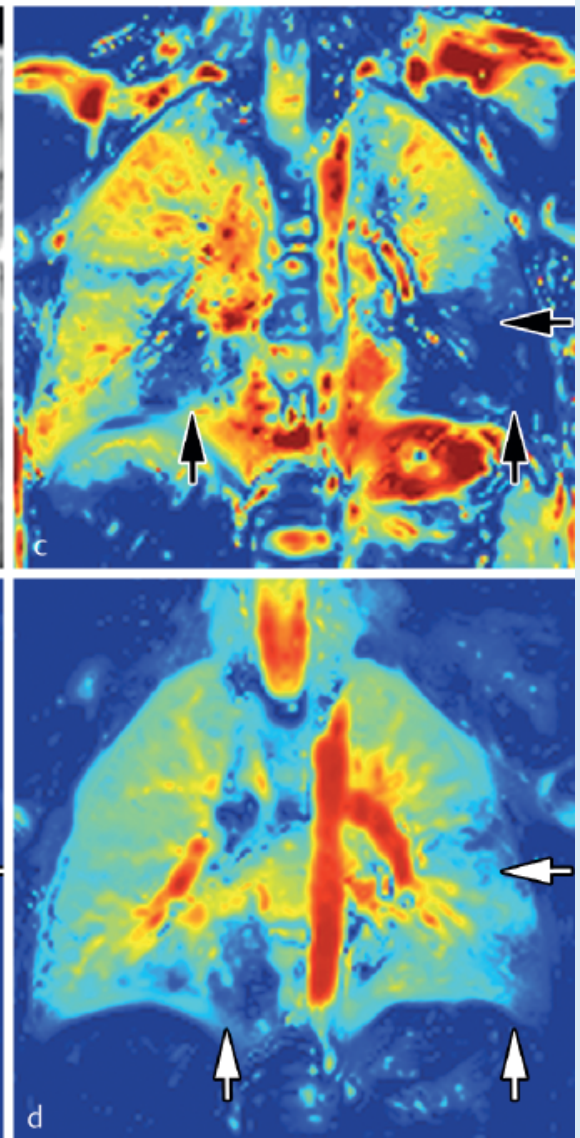

Fig. 7 Non-contrast enhanced combined ventilation and perfusion imaging with MRI. a, b Apart from areas with reduced parenchymal signal on T2weighted imaging (white arrowhead) this schoolage female with CF in stable clinical condition showed few airway abnormalities. Contrast-enhanced perfusion MRI revealed areas of reduced perfusion (white arrow, b), comparable to the aforesaid areas with reduced T2-signal. c, $\mathbf{d}$ Fourierdecomposition MRI detected nicely matching areas of reduced ventilation (black arrow, c) and perfusion (white arrow, d) without the need for contrast material injection.

Abb. 7 Kontrastmittelfreie kombinierte Bildgebung von Ventilation und Perfusion mittels MRT. a, b Neben flächigen Signalminderungen des Parenchyms in der T2-Wichtung (weißer Pfeilkopf) zeigte diese Patientin im Schulalter mit stabiler CF kaum Atemwegsveränderungen. Die kontrastmittelverstärkte Perfusions-MRT deckte deutliche Areale mit reduzierter Perfusion auf (weißer Pfeil, b), vergleichbar zu den vorgenannten Arealen mit T2-Signalminderung. c, d Die Fourier-Dekompositions-MRT erlaubte die Detektion von hierzu gut korrelierenden Arealen mit reduzierter Ventilation (schwarzer Pfeil, c) und Perfusion (weißer Pfeil, d) ohne die Notwendigkeit einer Kontrastmittelinjektion.
Table 2 Suggested imaging scheme according to experience in Heidelberg for life-long imaging surveillance of CF patients starting at birth.

Tab. 2 Heidelberger Schema als Vorschlag zum longitudinalen bildgebenden Monitoring der CF ab-Geburt.

\begin{tabular}{|llll|}
\hline & CXR & CT & MRI \\
\hline diagnosis, screening $<1$ year & $\mathrm{X}$ & & $\mathrm{X}(\mathrm{no} \mathrm{CM})$ \\
\hline diagnosis $\geq 1$ year & $\mathrm{X}$ & & $\mathrm{X}$ \\
\hline annual follow-up $<18$ years & $\mathrm{X}$ & & $\mathrm{X}$ \\
\hline annual follow-up $\geq 18$ years & $\mathrm{X}$ & & $\mathrm{X}$ \\
\hline clinical exacerbation & $\mathrm{X}$ & & $(\mathrm{X})$ \\
\hline emergency, hemorrhage & & $\mathrm{X}(\mathrm{CM})$ & \\
\hline
\end{tabular}

\section{$\mathrm{CM}=$ contrast material.}

$\mathrm{CM}=$ Kontrastmittel.

sequently led to an increase in radiation exposure to CF patients, which may even rise further with earlier diagnosis and prolonged survival [10]. A remaining role for CXR could be imaging at annual follow-up together with MRI as a cross-sectional modality for use of CXR as a reference when it is repeated at interim presentations between annual follow-up, for example in the case of exacerbation. Recently, chest MRI has entered clinical routine practice in CF [12]. Thus, radiologists and clinicians now can opt for the optimal modality adapted to the clinical context of their CF patients ( $\bullet$ Table 2 ). The risk of sedation in preschool children and allergies against MRI contrast material must be weighed against the risk from radiation exposure $[9,10,68]$. Importantly, to use MRI in CF as a routine surveillance tool is not limited to the depiction of structural information as with CT just using a radiation-free method. MRI's capability for combined morphological and functional imaging at sufficient spatial and high temporal resolution to obtain information on regional lung function should be taken into account as well. To appreciate its advantages over $\mathrm{CT}$, a perfusion study, which is available on most state-of-the-art MRI scanners already, should be included in the MRI protocol (๑ Fig. 1).

\section{Affiliations}

Department of Diagnostic and Interventional Radiology, Subdivision of Pulmonary Imaging, University Hospital of Heidelberg, Heidelberg, Germany Translational Lung Research Center Heidelberg (TLRC), Member of the German Lung Research Center (DZL), Heidelberg, Germany

Department of Diagnostic and Interventional Radiology with Nuclear Medicine, Thoraxklinik at the University Hospital of Heidelberg, Heidelberg, Germany

4 Radiologie Darmstadt, Groß-Gerau Community Hospital, Groß-Gerau, Germany

Department of Pulmonology and Respiratory Medicine, Cystic Fibrosis Center, Thoraxklinik at the University Hospital of Heidelberg, Heidelberg, Germany

6 Division of Pediatric Pulmonology \& Allergy and Cystic Fibrosis Center, Department of Pediatrics, University of Heidelberg, Heidelberg, Germany Department of Translational Pulmonology, University Hospital Heidelberg, Heidelberg, Germany

8 Department of Diagnostic and Interventional Radiology, Hufeland Hospital, Bad Langensalza, Germany

Conflicts of interest/Support statement: This study was supported by grants from the Bundesministerium für Bildung und Forschung (BMBF) to the German Center for Lung Research (DZL) (82DZL00401, 82DZL00402, 82DZL00404). Supported by a finan- 
cial grant from the Christiane Herzog Stiftung, Stuttgart, Germany, and the Mukoviszidose e.V. (S02/09), Bonn, the German Cystic Fibrosis Association. Technical support provided by Siemens Healthcare, Germany.

\section{References}

1 Stern $M$, Wiedemann $B$, Wenzlaff $P$. From registry to quality management: the German Cystic Fibrosis Quality Assessment project 1995 2006. Eur Respir J 2008; 31: 29-35

2 Sommerburg 0 , Hammermann J, Lindner $M$ et al. Five years of experience with biochemical cystic fibrosis newborn screening based on IRT/PAP in Germany. Pediatr Pulmonol 2015; 50: 655-664

3 Kerem E, Reisman J, Corey $M$ et al. Prediction of mortality in patients with cystic fibrosis. N Engl J Med 1992; 326: 1187-1191

4 Brody AS, Sucharew H, Campbell JD et al. Computed tomography correlates with pulmonary exacerbations in children with cystic fibrosis. Am J Respir Crit Care Med 2005; 172: 1128-1132

5 Terheggen-Lagro S, Truijens $N$, van Poppel $N$ et al. Correlation of six different cystic fibrosis chest radiograph scoring systems with clinical parameters. Pediatr Pulmonol 2003; 35: 441 - 445

6 de Jong PA, Lindblad A, Rubin L et al. Progression of lung disease on computed tomography and pulmonary function tests in children and adults with cystic fibrosis. Thorax 2006; 61: 80-85

7 Davis SD, Fordham LA, Brody AS et al. Computed tomography reflects lower airway inflammation and tracks changes in early cystic fibrosis. Am J Respir Crit Care Med 2007; 175: 943 - 950

8 Sly PD, Brennan S, Gangell C et al. Lung disease at diagnosis in infants with cystic fibrosis detected by newborn screening. Am J Respir Crit Care Med 2009; 180: 146-152

9 Donadieu J, Roudier C, Saguintaah M et al. Estimation of the radiation dose from thoracic CT scans in a cystic fibrosis population. Chest 2007; $132: 1233-1238$

10 O'Connell OJ, McWilliams S, McGarrigle A et al. Radiologic imaging in cystic fibrosis: cumulative effective dose and changing trends over 2 decades. Chest 2012; 141: 1575-1583

11 Wielpütz MO, Puderbach M, Kopp-Schneider A et al. Magnetic Resonance Imaging Detects Changes in Structure and Perfusion, and Response to Therapy in Early Cystic Fibrosis Lung Disease. Am J Respir Crit Care Med 2014; 189: 956-965

12 Wielpütz MO, Mall MA. Imaging modalities in cystic fibrosis: emerging role of MRI. Curr Opin Pulm Med 2015; 21: 609-616

13 Hansell DM, Bankier AA, MacMahon H et al. Fleischner Society: glossary of terms for thoracic imaging. Radiology 2008; 246: 697-722

14 Wormanns D, Hamer OW. Glossar thoraxradiologischer Begriffe entsprechend der Terminologie der Fleischner Society. Fortschr Röntgenstr 2015; 187: 638-661

15 Benden C, Wallis C, Owens CM et al. The Chrispin-Norman score in cystic fibrosis: doing away with the lateral view. Eur Respir J 2005; 26: $894-897$

16 O'Connor OJ, Vandeleur M, McGarrigle AM et al. Development of lowdose protocols for thin-section CT assessment of cystic fibrosis in pediatric patients. Radiology 2010; 257: 820-829

17 Kauczor HU, Wielpütz MO, Owsijewitsch M et al. Computed tomographic imaging of the airways in COPD and asthma. J Thorac Imaging 2011; 26: $290-300$

18 Mott LS, Park J, Gangell CL et al. Distribution of early structural lung changes due to cystic fibrosis detected with chest computed tomography. J Pediatr 2013; 163: 243-248 e241-243

19 Wielpütz MO, Eichinger M, Weinheimer $O$ et al. Automatic airway analysis on multidetector computed tomography in cystic fibrosis: correlation with pulmonary function testing. J Thorac Imaging 2013; 28 : $104-113$

20 Bankier AA, Schaefer-Prokop C, De Maertelaer V et al. Air trapping: comparison of standard-dose and simulated low-dose thin-section CT techniques. Radiology 2007; 242: 898-906

21 Hansell DM. Small airways diseases: detection and insights with computed tomography. Eur Respir J 2001; 17: 1294-1313

22 Eichinger M, Heussel CP, Kauczor HU et al. Computed tomography and magnetic resonance imaging in cystic fibrosis lung disease. J Magn Reson Imaging 2010; 32: 1370-1378

23 Kubo T, Lin PJ, Stiller W et al. Radiation dose reduction in chest CT: a review. Am J Roentgenol 2008; 190: 335-343

24 Stiller $W$. Grundlagen der Mehrzeilendetektor-Computertomografie. Der Radiologe 2011; 51: 1061 -1078
25 Sly PD, Gangell CL, Chen L et al. Risk factors for bronchiectasis in children with cystic fibrosis. N Engl J Med 2013; 368: 1963-1970

26 Hayes D Jr, Winkler MA, Kirkby S et al. Preprocedural planning with prospectively triggered multidetector row $\mathrm{CT}$ angiography prior to bronchial artery embolization in cystic fibrosis patients with massive hemoptysis. Lung 2012; 190: 221-225

27 Biederer J, Beer $M$, Hirsch W et al. MRI of the lung (2/3). Why ... when ... how? Insights Imaging 2012; 3: 355 - 371

28 Puderbach M, Eichinger M, Gahr J et al. Proton MRI appearance of cystic fibrosis: comparison to CT. Eur Radiol 2007; 17: 716-724

29 Puderbach M, Eichinger M, Haeselbarth J et al. Assessment of morphological MRI for pulmonary changes in cystic fibrosis (CF) patients: comparison to thin-section CT and chest x-ray. Invest Radiol 2007; 42: $715-725$

30 Biederer J, Heussel CP, Puderbach $M$ et al. Functional magnetic resonance imaging of the lung. Semin Respir Crit Care Med 2014; 35: 74-82

31 Dournes G, Grodzki D, Macey J et al. Quiet Submillimeter MR Imaging of the Lung Is Feasible with a PETRA Sequence at 1.5 T. Radiology 2015; 276: $258-265$

32 Lutterbey G, Wattjes MP, Doerr D et al. Atelectasis in children undergoing either propofol infusion or positive pressure ventilation anesthesia for magnetic resonance imaging. Paediatr Anaesth 2007; 17: 121 - 125

33 Blitman NM, Lee HK, Jain VR et al. Pulmonary atelectasis in children anesthetized for cardiothoracic MR: evaluation of risk factors. J Comput Assist Tomogr 2007; 31: 789-794

34 Loeve M, van Hal PT, Robinson P et al. The spectrum of structural abnormalities on $\mathrm{CT}$ scans from patients with $\mathrm{CF}$ with severe advanced lung disease. Thorax 2009; 64: 876-882

35 Chrispin AR, Norman AP. The systematic evaluation of the chest radiograph in cystic fibrosis. Pediatr Radiol 1974; 2: $101-105$

36 Mall MA, Hartl D. CFTR: cystic fibrosis and beyond. Eur Respir J 2014 44: $1042-1054$

37 Rosenfeld M, Ratjen F, Brumback L et al. Inhaled hypertonic saline in infants and children younger than 6 years with cystic fibrosis: the ISIS randomized controlled trial. JAMA 2012; 307: 2269-2277

38 Eibel $R$, Herzog P, Dietrich $O$ et al. Pulmonary abnormalities in immunocompromised patients: comparative detection with parallel acquisition MR imaging and thin-section helical CT. Radiology 2006; 241: $880-891$

39 Eichinger M, Optazaite DE, Kopp-Schneider A et al. Morphologic and functional scoring of cystic fibrosis lung disease using MRI. Eur J Radiol 2012; 81: $1321-1329$

40 Wielpütz MO, Weinheimer O, Eichinger M et al. Pulmonary emphysema in cystic fibrosis detected by densitometry on chest multidetector computed tomography. PLoS One 2013; 8: e73142

41 Mets OM, Roothaan SM, Bronsveld I et al. Emphysema Is Common in Lungs of Cystic Fibrosis Lung Transplantation Patients: A Histopathological and Computed Tomography Study. PLoS One 2015; 10: e0128062

42 Mall M, Grubb BR, Harkema JR et al. Increased airway epithelial Na+ absorption produces cystic fibrosis-like lung disease in mice. Nat Med 2004; 10: 487-493

43 Mall MA, Harkema JR, Trojanek JB et al. Development of chronic bronchitis and emphysema in $\beta$-epithelial $\mathrm{Na}+$ channel-overexpressing mice. Am J Respir Crit Care Med 2008; 177: 730 - 742

44 Wielpuetz $M O$, Eichinger $M$, Zhou $Z$ et al. In vivo monitoring of cystic fibrosis-like lung disease in mice by volumetric computed tomography. Eur Respir J 2011; 38: 1060 - 1070

45 Stern EJ, Müller NL, Swensen SJ et al. CT mosaic pattern of lung attenuation: etiologies and terminology. Journal of thoracic imaging 1995; 10 : 294-297

46 Hopkins SR, Wielpütz MO, Kauczor HU. Imaging lung perfusion. J Appl Physiol 2012; 113: 328-339

47 Eichinger M, Puderbach $M$, Fink $C$ et al. Contrast-enhanced 3D MRI of lung perfusion in children with cystic fibrosis-initial results. Eur Radiol 2006; 16: $2147-2152$

48 Brasfield $D$, Hicks $G$, Soong $S$ et al. The chest roentgenogram in cystic fibrosis: a new scoring system. Pediatrics 1979; 63: 24-29

49 Weatherly MR, Palmer CG, Peters ME et al. Wisconsin cystic fibrosis chest radiograph scoring system. Pediatrics 1993; 91: 488-495

50 Bhalla $M$, Turcios $N$, Aponte $V$ et al. Cystic fibrosis: scoring system with thin-section CT. Radiology 1991; 179: 783-788

51 Helbich TH, Heinz-Peer G, Eichler I et al. Cystic fibrosis: CT assessment of lung involvement in children and adults. Radiology 1999; 213: $537-$ 544 
52 Demirkazik FB, Ariyurek OM, Ozcelik $U$ et al. High resolution CT in children with cystic fibrosis: correlation with pulmonary functions and radiographic scores. Eur J Radiol 2001; 37: 54-59

53 Rosenow T, Oudraad MC, Murray CP. PRAGMA-CF. et al. A Quantitative Structural Lung Disease Computed Tomography Outcome in Young Children with Cystic Fibrosis. Am J Respir Crit Care Med 2015; 191: $1158-1165$

54 Bauman G, Puderbach M, Heimann T et al. Validation of Fourier decomposition MRI with dynamic contrast-enhanced MRI using visual and automated scoring of pulmonary perfusion in young cystic fibrosis patients. Eur J Radiol 2013; 82: 2371 - 2377

55 Kohlmann P, Strehlow J, Jobst B et al. Automatic lung segmentation method for MRI-based lung perfusion studies of patients with chronic obstructive pulmonary disease. Int J Comput Assist Radiol Surg 2014; 10: 15

56 Ohno Y, Hatabu H, Murase K et al. Quantitative assessment of regional pulmonary perfusion in the entire lung using three-dimensional ultrafast dynamic contrast-enhanced magnetic resonance imaging: Preliminary experience in 40 subjects. J Magn Reson Imaging 2004; 20: $353-365$

57 Risse F, Eichinger M, Kauczor HU et al. Improved visualization of delayed perfusion in lung MRI. Eur J Radiol 2011; 77: 105-110

58 van Beek EJ, Wild JM, Kauczor HU et al. Functional MRI of the lung using hyperpolarized 3-helium gas. J Magn Reson Imaging 2004; 20: $540-$ 554

59 Donnelly LF, MacFall JR, McAdams HP et al. Cystic fibrosis: combined hyperpolarized 3He-enhanced and conventional proton MR imaging in the lung-preliminary observations. Radiology 1999; 212: 885-889

60 Mentore K, Froh DK, de Lange EE et al. Hyperpolarized HHe 3 MRI of the lung in cystic fibrosis: assessment at baseline and after bronchodilator and airway clearance treatment. Acad Radiol 2005; 12: 1423-1429
61 van Beek EJ, Hill C, Woodhouse $N$ et al. Assessment of lung disease in children with cystic fibrosis using hyperpolarized 3-Helium MRI: comparison with Shwachman score, Chrispin-Norman score and spirometry. Eur Radiol 2007; 17: 1018-1024

62 Bannier E, Cieslar K, Mosbah K et al. Hyperpolarized 3He MR for sensitive imaging of ventilation function and treatment efficiency in young cystic fibrosis patients with normal lung function. Radiology 2010; 255: $225-232$

63 Triphan SM, Jobst BJ, Breuer FA et al. Echo time dependence of observed $\mathrm{T}$ in the human lung. J Magn Reson Imaging 2015; DOI: 10.1002/ jmri.24840

64 Stadler A, Jakob PM, Griswold $M$ et al. T1 mapping of the entire lung parenchyma: Influence of respiratory phase and correlation to lung function test results in patients with diffuse lung disease. Magn Reson Med 2008; 59: 96 - 101

65 Jakob PM, Wang T, Schultz $G$ et al. Assessment of human pulmonary function using oxygen-enhanced T(1) imaging in patients with cystic fibrosis. Magn Reson Med 2004; 51: 1009-1016

66 Bauman G, Scholz A, Rivoire J et al. Lung ventilation- and perfusionweighted Fourier decomposition magnetic resonance imaging: in vivo validation with hyperpolarized 3He and dynamic contrast-enhanced MRI. Magn Reson Med 2013; 69: 229-237

67 Müller FM, Bend J, Rietschel E et al. S3-Leitlinie „Lungenerkrankung bei Mukoviszidose “, Modul 1: Diagnostik und Therapie nach dem ersten Nachweis von Pseudomonas aeruginosa; 2013, http://www.awmf. org/uploads/tx_szleitlinien/026-0221_S3_Lungenerkrankung_bei_ Mukoviszidose_Modul_1_2013-06_01.pdf

68 Kuo W, Ciet P, Tiddens HA et al. Monitoring cystic fibrosis lung disease by computed tomography. Radiation risk in perspective. Am J Respir Crit Care Med 2014; 189: 1328 - 1336

69 Stöver B, Rogalla P. CT-Untersuchungen bei Kindern. Der Radiologe 2008; 48: $243-248$ 